\title{
Concentration of Monoterpenoids in the Rumen Ingesta of Wild Mule Deer
}

\author{
L.K. CLUFF, B.L. WELCH, J.C. PEDERSON, AND J.D. BROTHERSON
}

\begin{abstract}
Forage from a sagebrush-dominated winter range and rumen ingesta from mule deer wintering on this range were analyzed for monoterpenoids. The average monoterpenoid level of the rumen ingesta was $0.3 \%$, compared with an average of $1.64 \%$ expected from the proportion of monoterpenoid-containing plants in the diet. This $80 \%$ reduction between the monoterpenoid level from the rumen compared to the level expected from the ingested forage was highly significant $(p<.01)$. The exact method in which the monoterpenoids are lost from the ingesta was not determined, but evidence from other studies suggests that monoterpenoids may be lost from ingested forage as early as the mastication process. The amount of monoterpenoids found in the rumen ingesta at the time of sampling does not appear to be high enough to interfere with microbial activity. This loss of monoterpenoids may explain the conflict between in vitro evidence that big sagebrush monoterpenoids inhibit rumen microorganisms and digestive trials which show that big sagebrush is a highly digestible winter forage.
\end{abstract}

In the Great Basin and Rocky Mountain regions, big sagebrush (Artemisia tridentata) is an important winter browse species for mule deer (Odocoileus hemionus) (Smith 1950, Plummer et al. 1968, Kufeld et al. 1973, McArthur et al. 1979, Willms et al. 1979).

Through in vitro techniques, Nagy et al. (1964) found that the monoterpenoids from big sagebrush suppressed the growth rate of the rumen microorganisms, decreased the rate of cellulose digestion, and decreased the rate of gas and volatile fatty acid production by the microorganisms. Others have also hypothesized that when big sagebrush is consumed in high enough levels $(15-30 \%$ of the total diet), the monoterpenoids interfere with digestion (Nagy and Tengerdy 1968, Dietz and Nagy 1976, Nagy and Regelin 1977, Wallmo et al. 1977, Carpenter et al. 1979). Other wildlife species

\footnotetext{
Authors are graduate student, Department of Botany and Range Science, Brigham Young University, Provo, Utah 84602; research plant physiologist, Intermountain Forest and Range Experiment Station, Shrub Sciences Laboratory. Provo, Utah 84601; regional game manager, Utah Division of Wildlife Resources, Springville, Utah 84663; and associate professor of botany and range science. Brigham Young University, Provo, Utah 84602.

The authors extend thanks to Drs. David L. Nelson, Dean E. Medin, E. Durant McArthur, and Hal L. Black for their technical review of this paper

Manuscript received May 5, 1980.
}

besides mule deer, such as pygmy rabbits (Brachylagus idahoensis) (Wild 1978, Green and Flinders 1980, White et al. 1982), pronghorn antelope (Antilocapra americana) (Smith et al. 1965, Sund strom et al. 1973), and sagegrouse (Centrocercus urophasianus) (Braun et al. 1977), are known to consume large amounts of big sagebrush without any known adverse effects.

Previous studies reviewed by Welch and McArthur (1979) concerning the digestibility of big sagebrush lack sufficient evidence to prove that monoterpenoids interfere with digestion (also see Ward 1971). Through in vitro means, Welch and Pederson (1981) reported evidence that big sagebrush is a highly digestible winter browse species for mule deer. They found no significant relationship between the total monoterpenoid content of the sagebrush accessions and digestibility. They suggested that monoterpenoids may be lost from the forages through either mastication, eructation, absorption, or a combination of these processes and, therefore, may not interfere with rumen microorganisms. The purpose of this study is to test the hypothesis that the monoterpenoid level in the rumen ingesta is significantly less than expected from the forage ingested.

\section{Materials and Methods}

\section{Study Area}

Mule deer rumen ingesta samples and vegetative samples of monoterpenoid producing plants were taken off a mule deer winter range that runs next to U.S. highway 50 from Spanish Fork, Utah, to 10-15 miles east of Thistle, Utah. Here about 1,200 mule deer winter within a few hundred meters of the highway. This is due to two topographical features: high, steep mountains (80-120\% slopes) and narrow valleys. The result is that a great number of wintering mule deer are bunched onto small areas. During our study, the deer were confined to a vertical distance of 396 meters $(1,300 \mathrm{feet})-1524$ meters to 1920 meters $(5,000$ feet to $6,300 \mathrm{feet})$. It has been our observation for the past five winters that deer in a given area along this highway moved less than 1207 meters (3/4 of a mile). This condition exists elsewhere in Utah and in other states (Dorrance 1966). Because of this congestion of deer and motorized traffic, many road kills occur. We selected areas along U.S high- 
way 50 to collect rumen ingesta from fresh road kills. A road kill was considered fresh if the body felt warm to the touch, was slightly bloated on the left side, and the surface blood was uncoagulated. A major consideration for choosing a given area was the homogeneous a ppearance of the monoterpenoid producing plants. Five road kills were used along U.S. highway 50 . Three other road kills were used along other highways of central Utah found under the same conditions as for U.S. highway 50 . In addition, four mule deer were shot by personnel from the Utah Division of Wildlife Resources (DWR) on winter ranges dominated by sagebrush. These twelve deer were sampled during a period from January 10 to February 28.

\section{Rumen Ingesta}

Rumen samples were collected by immediately taking a mixed sample of ingesta out of the rumen and placing the sample in a plastic bag. Next, liquid nitrogen (about $900 \mathrm{ml}$ ) was poured on the sa mple, thus, quickly freezing the sample and preventing the loss of monoterpenoids. Because the plastic bags often cracked from the extreme cold of the liquid nitrogen $\left(-196^{\circ} \mathrm{C}\right)$ (Weast 1976), the frozen samples were placed in a second plastic bag and secured. Rumen ingesta samples were stored in a freezer at $-30^{\circ} \mathrm{C}$ until needed for monoterpenoid determinations and for determining the amount of monoterpenoid producing plants in the ingesta.

To determine the monoterpenoid levels in rumen ingesta, the samples were first thawed, mixed and $33 \mathrm{~g}$ placed in a $250-\mathrm{ml}$ erlenmeyer flask. Approximately $100 \mathrm{ml}$ of absolute ether was added to each flask to extract the monoterpenoids. The flasks were rotated at $200 \mathrm{rpm}$ for 8 hours. Then the ether was decanted off and the ether extracts concentrated by vacuum to $20-30 \mathrm{ml}$. Next, $1 \mathrm{ml}$ of a carvone standard $(31.25 \mathrm{~g} / 250 \mathrm{ml}$ in ether) was added to the extracts. Ether was then added to bring the volume of each sample to $50 \mathrm{ml}$. At the same time that samples were removed from the ingesta for monoterpenoids extraction, portions of the ingesta were also removed and analyzed to determine the dry matter content and the a mount of monoterpenoid producing plants (sagebrush, juniper, and rabbitbrush).

Amount of monoterpenoid-producing plants was determined by first screening the individual ingesta samples with a $2-\mathrm{mm}$ screen using cold tap water and then separating the particles into four categories: sagebrush, juniper, rabbitbrush, and other. Segregated plant material was then placed in aluminum dishes and oven dried for a minimum of 30 hours at $100^{\circ} \mathrm{C}$. From the oven-dried weights, the percentage of the four plant categories was determined. The percentages of sagebrush, juniper, and rabbitbrush in the various rumen ingesta samples were used to calculate expected monoterpenoid levels in the ingesta.

\section{Vegetative Sampling}

Vegetative samples of monoterpenoid-producing plants were collected a full 24 hours after taking the rumen samples from the road-killed deer and those shot. We took the same tissue off the plants as was eaten by the deer. Only browsed plants within 305 meters ( 1,000 feet) of where the deer were killed were sampled. These samples were placed in small plastic bags and packed in snow to prevent monoterpenoid loss. The vegetation samples were stored in a freezer $\left(-30^{\circ} \mathrm{C}\right)$ until needed for monoterpenoid determination. We used a method described by Welch and McArthur (1981) to determine the concentration of monoterpenoid in the vegetative samples. Data were expressed on a dry matter basis.

The amount of monoterpenoid in sagebrush, juniper, and rabbitbrush from the various collecting areas was used to calculate the expected monoterpenoids levels in the various ingesta. Expected values were compared to actual values by using a paired " $t$ " test.

\section{Results}

The mean vegetative composition of the ingesta was $18.5 \%$, $29.7 \%, 8.9 \%$, and $42.8 \%$ for sagebrush, juniper, rabbitbrush, and others, respectively (Table 1). The vegetative composition of the ingesta samples varied greatly among the deer, with the range of
Table 1. Amount of monoterpenoid-containing plants: big sagebrush (Artemisia tridentata), juniper (Juniperus osteosperma), and rabbitbrush (Chrysothamnus nauseosus) and total monoterpenoid containing plants found in the rumen ingesta of 12 wintering mule deer, expressed as percent of dry matter.

\begin{tabular}{lcccc}
\hline \hline Deer & $\begin{array}{c}\text { Sagebrush } \\
(\%)\end{array}$ & $\begin{array}{c}\text { Juniper } \\
(\%)\end{array}$ & $\begin{array}{c}\text { Rabbitbrush } \\
(\%)\end{array}$ & $\begin{array}{c}\text { Total } \\
(\%)\end{array}$ \\
\hline 1 & 0.39 & 45.54 & - & 45.93 \\
$2^{1}$ & 34.01 & 6.45 & - & 40.46 \\
3 & .37 & 83.13 & - & 83.50 \\
4 & 22.74 & 33.59 & 4.63 & 60.96 \\
5 & 9.27 & 8.55 & 58.86 & 76.68 \\
6 & 30.13 & 9.82 & .55 & 40.50 \\
$7^{*}$ & .24 & 56.72 & - & 56.96 \\
8 & 18.24 & 10.54 & 3.19 & 31.97 \\
9 & 40.93 & 1.44 & 8.45 & 50.82 \\
10 & 23.55 & 1.05 & 29.05 & 53.65 \\
$11^{1}$ & 7.19 & 56.32 & 2.28 & 65.79 \\
$12^{1}$ & 35.05 & 43.67 & .31 & 79.03 \\
Mean & 18.51 & 29.74 & 8.94 & 57.19 \\
\hline
\end{tabular}

'Deer killed by personnel from the Utah Division of Wild life Resourecs. Others werc highway or railroad kills.

sagebrush from $0.2 \%$ to $40.9 \%$, and juniper $1.1 \%$ to $83.1 \%$, and rabbitbrush $0.0 \%$ to $58.9 \%$. On a dry matter basis, an average $57.2 \%$ of the ingesta was composed of plants that contain high levels of monoterpenoids.

A necropsy was performed on the four deer shot by the DWR (numbers 2, 7,11, and 12) to determine the health status of each; they received ratings of 70 (good), 85 (excellent), 60 (fair), and 70 (good), respectively (Kistner et al. 1980). The percentage of plants containing monoterpenoids found in the rumen ingesta of these deer was $40.5 \%, 56.9 \%, 65.8 \%$, and $79.0 \%$, respectively, on a dry matter basis. There appeared to be no correlation between health condition and amount of monoterpenoid-containing plants in the ingesta.

There was an average loss of $80 \%$ of the monoterpenoids from the rumen (Table 2), with a range of $62 \%$ to $98 \%$. The difference between the observed expected levels of monoterpenoids was highly significant $(P<.01)$.

The mean monoterpenoid content for sagebrush, juniper, and rabbitbrush on a dry weight basis was $2.7 \%, 4.2 \%$, and $0.4 \%$, respectively (Table 3 ), which compares favorably with the findings of other investigators (Jobman 1972, Sheehy 1975, Nagy and Tengerdy 1968, Welch and McArthur 1981).

\section{Discussion}

The results of this study support the hypothesis that the mono-

Table 2. Expected and observed amounts of monoterpenoids in rumen ingesta of 12 wintering mule deer expressed as percent of dry matter.

\begin{tabular}{lcccc}
\hline \hline $\begin{array}{l}\text { Deer } \\
\text { number }\end{array}$ & $\begin{array}{c}\text { Observed } \\
(\%)\end{array}$ & $\begin{array}{c}\text { Expected } \\
(\%)\end{array}$ & $\begin{array}{c}\text { Difference } \\
(\%)\end{array}$ & $\begin{array}{c}\text { Reduction } \\
(\%)\end{array}$ \\
\hline 1 & 0.03 & 1.78 & 1.75 & 98.3 \\
$2^{1}$ & .13 & 1.55 & 1.42 & 91.6 \\
3 & .29 & 3.00 & 2.71 & 90.3 \\
4 & .51 & 2.28 & 1.77 & 77.6 \\
5 & .18 & .47 & .29 & 61.7 \\
6 & .36 & 1.95 & 1.59 & 81.5 \\
71 & .19 & 1.08 & .89 & 82.4 \\
8 & .17 & .80 & .63 & 78.8 \\
9 & .27 & 1.37 & 1.10 & 80.3 \\
10 & .39 & 1.11 & .72 & 64.9 \\
$11^{1}$ & .55 & 2.49 & 1.94 & 77.9 \\
$12^{1}$ & .55 & 1.85 & 1.30 & 70.3 \\
Mean & .30 & 1.64 & 1.34 & 79.6 \\
\hline
\end{tabular}

' Deer killed by personnel from the Utah Division of Wildlife Resources. Others were highway or railroad kills. 
Table 3. Amount of monoterpenoids from winter range plants collected in the immediate vicinity from which each mule deer rumen sample was obtained, expressed as percent of dry matter.

\begin{tabular}{lccc}
\hline $\begin{array}{l}\text { Deer } \\
\text { number }\end{array}$ & $\begin{array}{c}\text { Sagebrush } \\
(\%)\end{array}$ & $\begin{array}{c}\text { Juniper } \\
(\%)\end{array}$ & $\begin{array}{c}\text { Rabbitbrush } \\
(\%)\end{array}$ \\
\hline 1 & 1.9 & 3.9 & - \\
2 & 2.4 & 11.5 & - \\
3 & 1.7 & 3.6 & - \\
4 & 3.5 & 4.4 & .1 \\
5 & 1.5 & .4 & .5 \\
6 & 4.6 & 5.7 & .5 \\
7 & 2.2 & 1.9 & - \\
8 & 1.8 & 4.3 & .7 \\
9 & 3.1 & 3.8 & .5 \\
10 & 4.4 & 4.1 & .1 \\
11 & 3.2 & 4.0 & .3 \\
12 & 2.1 & 2.7 & - \\
Mean & 2.7 & 4.2 & .4 \\
\hline
\end{tabular}

terpenoid level in the rumen ingesta is significantly less than expected from the forage ingested. These results are supported by a similar study conducted with pygmy rabbits (White et al. 1982) which shows that about $77 \%$ of the monoterpenoids from sagebrush is lost from the stomach of the rabbits. The loss of monoterpenoids may be due to one or more of the following: mastication, rumination, eructation, absorption through the rumen wall into the cardiovascular system and excreted in the urine or metabolized in the liver (Annison 1965, Cook et al. 1952, Welch and Pederson 1981). White et al. (1982) found evidence of the loss of monoterpenoides through mastication by pygmy rabbits.

Amino acids, volatile fatty acids, and other substances are absorbed through the rumen wall into the cardiovascular system (Annison 1965). The molecular weights of monoterpenoids (136.24-156.27) (Weast 1976) fall within the range of the molecular weights for amino acids (75.07-204.23). which on a size basis suggests that monoterpendoids could be lost through absorption as suggested by Cook et al. (1952).

Some workers have concluded from in vitro studies that digestion problems could arise in mule deer when big sagebrush reaches 15 to $30 \%$ of the diet (Dietz and Nagy 1976, Wallmo et al. 1977, Carpenter et al. 1979). Of course, these workers couldn't have taken into consideration in their estimates our discovery concerning the large loss of monoterpenoids from ingested forages. This would substantially raise the level of big sagebrush and other monoterpenoid-producing plants that can be safely consumed. Also, our data show that the rumen contents of the four healthy mule deer shot by the DWR were composed on a dry weight basis of 40.5 to $79.0 \%$ of plant material containing high levels of monoterpenoids.

Since our results show significant loss of the "toxic" monoterpenoids from big sagebrush, juniper, and rabbitbrush occurs in the early stages of the digestion process, the nutritional dilemma referred to by Wallmo et al. (1977) is probably not as great as first thought. Also, this loss of monoterpenoids helps to explain the conflict between in vitro evidence that big sagebrush monoterpenoids (also juniper) inhibit rumen microorganisms and digestive trials which show that big sagebrush is a highly digestable winter forage.

\section{Literature Cited}

Annison, E.F. 1965. Absorption from the ruminant stomach. In: R.W. Dougherty (ed.). Physiology of Digestion in the Ruminant. Washington, Butterworths. p. 185-197.
Braun, C.E., T. Britt, and R.D. Wallestad. 1977. Guidelines for maintenance of sage grouse habitats. Wildl. Soc. Bull. 5:99-106.

Carpenter, L.H., O.C. Wallmo, and R.B. Gill. 1979. Forage diversity and dietary selection by wintering mule deer. J. Range Manage. 32:226-229.

Cook, C.W., L.A. Stoddart, and L.E. Harris. 1952. Determining the digestibility and metabolizable energy of winter range plants by sheep. J. Animal Sci. 11:578-590.

Dietz, D.R., and J.G. Nagy. 1976. Mule deer nutrition and plant utilization. p. 71-78. In: G.W. Workman and J.B. Low (eds.) Mule Deer Decline in the West-A Symposium. College Natur. Resour. Utah Agr. Exp. Sta., Iogan. 134 p.

Dorrance, M.J. 1966. A literature review on behavior of mule deer. Sp. Rep. \#7, Colorado Dep. of Game, Fish, and Parks-Game Research Division.

Green, J.R., and J.T. Flinders. 1980. Habitat and dietary relationship of the pygmy rabbit. J. Range Manage. 33:136-142.

Jobman, W.G. 1972. Consumption of juniper by deer and inhibition of rumen microorganisms by volatile oils of juniper. M.S. Thesis. Colorado State Univ., Fort Collins. 51 p.

Kistner, T.P., C.E. Trainer, and N.A. Hartmann. 1980. A field technique for evaluating physical condition of deer. Wildl. Soc. Bull. 8:11-17.

Kufeld, R.C., O.C. Wallmo, and C. Feddema. 1973. Foods of the Rocky Mountain mule deer. U.S. Dep. Agr. Forest Serv. Res. Pap. RM-111,31 p. Rocky Mtn. Forest and Range Exp. Sta., Fort Collins, Colo.

McArthur, E.D., A.C. Blauer, A.P. Plummer, and R. Stevens. 1979. Characteristics and hybridization of important intermountain shrubs. III. Sunflower family. U.S. Dep. Agr. Forest Serv. Res. Pap. INT-220, 82 p. Intermt. Forest and Range Exp. Sta., Ogden, Utah.

Nagy, J.G., and R.P. Tengerdy. 1968. Antibacterial action of essential oils of Artemisia as an ecological factor. II. Antibacterial action of the volatile oils of Artemisia tridentata (big sagebrush) on bacteria from the rumen of mule deer. Appl. Microbiol. 16:441-444.

Nagy, J.G., and W.L. Regelin. 1977. Influence of plant volatile oils on food selection by animals. 13th Congress of Game Biol. 13:225-230.

Plummer, A.P., D.R. Christensen, and S.B. Monsen. 1968. Restoring big game range in Utah. Utah Div. of Wildl. Resour., Fish and Game Publ. 68-3. 183 p.

Sheehy, D.P. 1975. Relative palatability of seven Artemisia taxa to mule deer and sheep. M.S. Thesis. Oregon State Univ., Corvallis. 147 p.

Smith, A.D. 1950. Sagebrush as winter feed for mule deer. J. Wildl. Manage. 14:285-289.

Smith, A.D., D.M. Beale, and D.D. Doell. 1965. Browse preference of pronghorn antelope in southwestern Utah. Trans. North Amer. Wildl. Nat. Res. Conf. 30:136-141.

Sundstrom, C., W.G. Hepworth, and K.I. Diem. 1973. Abundance, distribution, and food habits of the pronghorn. Wyoming Game and Fish Comm. Cheyenne. Bull. No. 12, 24 p.

Wallmo, O.C., L.H. Carpenter, W.L. Regelin, R.B. Gill, and D.L. Baker. 1977. Evaluation of deer habitat on nutritional basis. J. Range Manage. 30:122-127.

Ward, A.L. 1971. In vitro digestibility of elk winter forage in southern Wyoming. J. Wildl. Manage. 35:681-688.

Weast, R.C. 1976. Handbook of Chemistry and Physics. 56th Ed. CRC Press, Cleveland, Ohio.

Welch, B.L., and E.D. Mc Arthur. 1979. Feasibility of improving big sagebrush (Artemisia tridentata) for use on mule deer winter ranges. In: J.R. Goodin and D.K. Northington (eds.). Proc. Internat. Arid Lands Conf. on Plant Res. Texas Tech. Univ., Lubbock. p. 451-473.

Welch, B.L., and E.D. McArthur. 1981. Variation of monoterpenoid content among subspecies and accessions of Artemisia tridentata grown in a uniform garden. J. Range Manage. 34.

Welch, B.L., and J.C. Pederson. 1981. In vitro digestibility among accessions of big sagebrush by wild mule deer and its relationship to monoterpenoid content. J. Range Manage. 34:497-500.

White, S.M., B.L. Welch, and J.T. Flinders. 1982. Monoterpenoid content of pygmy rabbit stomach contents. J. Range Manage. 35:107-109.

Wilde, D.B. 1978.A population analysis of the pygmy rabbits (Sylvilagus idahoensis) on the INEL site. Ph.D. Diss., Idaho State Univ., Pocatello. $172 \mathrm{p}$.

Willms, W., A. McLean, R. Tucker, and R. Ritcey. 1979. Interactions between mule deer and cattle on big sagebrush range in British Columbia. J. Range Manage. 32:299-304. 